\title{
Diagnostic value of lipopolysaccharide-binding protein and procalcitonin for sepsis diagnosis in forensic pathology
}

\author{
Marc Augsburger • Katia Iglesias • Daniel Bardy • \\ Patrice Mangin • Cristian Palmiere
}

Received: 18 June 2012 / Accepted: 4 October 2012 /Published online: 13 October 2012

(C) Springer-Verlag Berlin Heidelberg 2012

\begin{abstract}
The aims of this study were twofold. The first was to investigate the diagnostic performance of two biochemical markers, procalcitonin (PCT) and lipopolysaccharide-binding protein (LBP), considering each individually and then combined, for the postmortem diagnosis of sepsis. We also tested the usefulness of pericardial fluid for postmortem LBP determination. Two study groups were formed, a sepsis-related fatalities group of 12 cases and a control group of 30 cases. Postmortem native CT scans, autopsy, histology, neuropathology, and toxicology as well as other postmortem biochemical investigations were performed in all cases. Microbiological investigations were also carried out in the septic group. Postmortem serum PCT and LBP levels differed between the two groups. Both biomarkers, individually considered, allowed septic states to be diagnosed, whereas increases in both postmortem serum PCT and LBP levels were only observed in cases of sepsis. Similarly, normal PCT and LBP values in postmortem serum were identified only in non-septic cases. Pericardial fluid LBP levels do not correlate with the presence of underlying septic states. No relationship was observed
\end{abstract}

Marc Augsburger and Cristian Palmiere equally contributed as first authors to this work.

M. Augsburger · P. Mangin · C. Palmiere $(\bowtie)$

University Centre of Legal Medicine,

Rue du Bugnon 21,

1011 Lausanne, Switzerland

e-mail: cristian.palmiere@chuv.ch

K. Iglesias

Institute of Social and Preventive Medicine,

Lausanne University Hospital,

Rue du Bugnon 17,

1004 Lausanne, Switzerland

D. Bardy

Laboratory of Clinical Chemistry, Lausanne University Hospital, 1011 Lausanne, Switzerland between postmortem serum and pericardial fluid LBP levels in either septic or non-septic groups, or between pericardial fluid PCT and LBP levels.

Keywords Lipopolysaccharide-binding protein (LBP) · Procalcitonin $\cdot$ Sepsis $\cdot$ Postmortem biochemistry

\section{Introduction}

Reliable diagnosis of sepsis remains a major challenge for forensic pathologists despite extensive research and development in immunohistochemistry and postmortem biochemistry. Medical records are often unavailable when autopsy is performed, and macroscopic and microscopic data may be elusive. Much effort has therefore been directed toward identifying clinical biochemical parameters whose measurements in the forensic casework might provide additional information and represent a reliable tool for estimating the probability of sepsis as cause of death. Biochemical markers of inflammation and sepsis have mainly been tested in postmortem serum from femoral blood and experimentally measured in other biological substrates, such as pericardial fluid [1], vitreous humor, cerebrospinal fluid [2], and liver [3], at times with promising results.

Several investigations in living people have confirmed the usefulness of C-reactive protein (CRP) and procalcitonin (PCT) as biochemical markers for the diagnosis of systemic inflammation and bacterial sepsis. In the forensic field, these parameters can easily be measured in peripheral and cardiac blood as well as in postmortem serum. Furthermore, they may be used for forensic purposes as in clinical practice. Nevertheless, the diagnostic power of these markers in detecting sepsis-related fatalities is somehow unsatisfactory. Indeed, some clinical studies have positively evaluated high plasma CRP levels in patients with infection and sepsis, 
whereas results from many other studies have failed to show the impact of elevated CRP levels for either the diagnosis of infection and sepsis or the assessment of sepsis severity [4, 5]. CRP plasma levels may furthermore remain elevated several days after elimination of the infectious focus and increased levels have been described in many noninfectious conditions, such as autoimmune and rheumatic disorders, acute coronary syndromes, and malignant tumors post-surgery [5-8].

PCT elevation may already be recognized just $2 \mathrm{~h}$ after endotoxemia or bacteremia $[9,10]$. Nevertheless, as with CRP, there are a number of noninfectious causes that may result in increased PCT levels apart from bacterial infections, such as major surgery, severe trauma, exertional heat stroke, or burns [11-15]. Plasma concentrations observed under these conditions are not as high, however, as in patients with severe sepsis or septic shock [5]. Increased PCT values have also been described, together with other signs of systemic inflammation, in prolonged cardiogenic shock, likely in relation to endotoxin translocation after gastrointestinal perfusion impairment $[16,17]$.

Lipopolysaccharide (LPS)-binding protein (LBP) was initially discovered by Tobias in 1986 as an acute-phase reactant binding the LPS of Gram-negative bacteria wall to form LPSLBP complexes $[18,19]$. Biochemically, LBP is a $50-\mathrm{kDa}$ polypeptide, mainly synthesized in the hepatocytes and released into the bloodstream as a $58-60-\mathrm{kDa}$ glycoprotein resulting from glycosylation. The human form consists of 452 amino acid residues in the mature protein with the typical 25-aminoacid signal sequence that characterizes secreted proteins.

LBP is constitutively present in serum at concentrations of $2-10 \mu \mathrm{g} / \mathrm{ml}$. Levels may increase during the acute-phase reaction [20] to reach peaks of up to $200 \mu \mathrm{g} / \mathrm{ml}$ [21].

Elevated LBP plasma levels have been described in earlyonset neonatal sepsis $[22,23]$ and in adults after extensive cardiothoracic surgical procedures [24, 25]. A clinical study performed by Meynaar et al. [24] concluded that PCT levels were more helpful than LBP values in differentiating sepsis from systemic inflammatory response syndrome (SIRS) in critically ill patients admitted to hospital.

In the field of forensic pathology, Reichelt et al. [25] monitored the postmortem course of three endogenous biomarkers, including LBP, in a series of sepsis-related fatalities and non-septic control individuals during the early postmortem period. They concluded that LBP levels higher than $10 \mu \mathrm{g} / \mathrm{ml}$ in peripheral and venous blood could be regarded as diagnostic hints for underlying sepsis in the deceased. This appeared especially significant when at least two measurements were performed at different postmortem times in order to estimate the most probable LBP level at death.

In the study herein presented, PCT and LBP levels were measured in postmortem serum from femoral blood and pericardial fluid in a series of sepsis-related fatalities and control individuals. The first objective of this study was to assess the diagnostic performance of both parameters, combined or individually considered, to detect sepsis-related fatalities. The second aim was to compare pericardial fluid to postmortem serum LBP levels to test the usefulness of pericardial fluid for biochemical investigations. Postmortem native CT scans, autopsy, histology, neuropathology, and toxicology as well as other postmortem biochemical analyses were performed in all cases selected for this study.

\section{Material and methods}

\section{Subjects}

Two study groups were formed: a sepsis-related fatalities group and a control group. The sepsis-related fatalities group consisted of 12 forensic autopsy cases (six males, six females, no children) with a mean age of 52.7 years (range 17-80 years).

None of the subjects included in this group had a documented diagnosis of sepsis in vivo and none had been admitted to the hospital prior to death. Medical records obtained prior to autopsies were consistent with the hypothesis that underlying bacterial sepsis might be at the origin of or contributing to death. Autopsies were ordered by the public prosecutor due to the unclear circumstances of death and the bodies were transferred to the medicolegal center.

For all cases included in this group, complete forensic autopsies were performed within 5-62 h after death (mean postmortem period $22.6 \mathrm{~h}$ ), always preceded by native CT scans. Histology, neuropathology, and toxicology were performed in all cases as well as microbiological investigations on right cardiac blood.

Postmortem biochemical investigations were carried out on postmortem serum from femoral blood (procalcitonin, CRP, LBP, troponin I, NT-proBNP, tryptase, urea nitrogen, creatinine, and uric acid), whole blood (3-beta-hydroxybutyrate), vitreous humor (glucose, sodium, chloride), and pericardial fluid (procalcitonin, LBP).

The cause of death was attributed to multiple organ failure based on the results of postmortem investigations as well as the exclusion of other causes of death. Underlying bacterial septic states were postulated to be at the origin of the multiple organ failures. Descriptive characteristics of the investigated subjects and main postmortem investigation findings are reported in Table 1.

The control group consisted of 30 forensic autopsy cases. None of the subjects included in this group had a documented, clinical diagnosis of sepsis in vivo and none had been admitted to the hospital prior to death. Complete forensic autopsies were performed between 8 and $51 \mathrm{~h}$ after death (mean $24.4 \mathrm{~h}$ ), always preceded by native CT scans. Histology, neuropathology, and toxicology were performed in all cases, as well as biochemical 
Table 1 Summarizes the characteristics of the investigated subjects (septic cases, $n=12$, six males, six females, mean age 52.7), laboratory results, and main postmortem investigation findings

\begin{tabular}{|c|c|c|c|c|c|c|c|c|}
\hline $\begin{array}{l}\text { Subject and } \\
\text { postmortem } \\
\text { interval }\end{array}$ & Age & Gender & $\begin{array}{l}\text { Postmortem serum } \\
\text { procalcitonin }\end{array}$ & $\begin{array}{l}\text { Pericardial fluid } \\
\text { procalcitonin }\end{array}$ & $\begin{array}{l}\text { Postmortem } \\
\text { serum LBP }\end{array}$ & $\begin{array}{l}\text { Pericardial } \\
\text { fluid LBP }\end{array}$ & $\begin{array}{l}\text { Microbiology } \\
\text { findings }\end{array}$ & $\begin{array}{l}\text { Main postmortem } \\
\text { investigation findings } \\
\text { and medical records }\end{array}$ \\
\hline $\begin{array}{l}1 \\
25 \mathrm{~h}\end{array}$ & 46 & $\mathrm{~F}$ & 23.37 & 13.84 & 6.1 & 6.0 & m.b. & Peritonitis \\
\hline $\begin{array}{l}2 \\
34 \mathrm{~h}\end{array}$ & 70 & M & 2.62 & 2.34 & 16.2 & 5.8 & $P$. aeruginosa & $\begin{array}{l}\text { Necrotizing myocarditis } \\
\text { Fibrinous pericarditis } \\
\text { Pneumonia }\end{array}$ \\
\hline $\begin{array}{l}3 \\
15 \mathrm{~h}\end{array}$ & 48 & $\mathrm{~F}$ & 13.50 & 9.24 & 37.7 & 4.4 & E. coli & Pyelonephritis \\
\hline $\begin{array}{l}4 \\
14 \mathrm{~h}\end{array}$ & 49 & M & 0.06 & 0.06 & 15.4 & 6.0 & m.b. & $\begin{array}{l}\text { Pneumonia } \\
\text { Antibiotic treatment }\end{array}$ \\
\hline $\begin{array}{l}5 \\
14 \mathrm{~h}\end{array}$ & 80 & $\mathrm{~F}$ & 2.76 & 2.30 & 70.1 & 10.2 & E. coli & Pneumonia \\
\hline $\begin{array}{l}6 \\
5 \mathrm{~h}\end{array}$ & 57 & $\mathrm{~F}$ & 155.70 & 80.15 & 68.7 & 9.5 & m.b. & Abdominal infection \\
\hline $\begin{array}{l}7 \\
62 \mathrm{~h}\end{array}$ & 63 & $\mathrm{~F}$ & 13.62 & 10.5 & 29.4 & 4.6 & m.b. & Peritonitis \\
\hline $\begin{array}{l}8 \\
21 \mathrm{~h}\end{array}$ & 74 & $\mathrm{~F}$ & 2.31 & 1.75 & 19.8 & 6.7 & m.b. & $\begin{array}{l}\text { Alzheimer } \\
\text { Broncho-aspiration } \\
\text { Pneumonia }\end{array}$ \\
\hline $\begin{array}{l}9 \\
12 \mathrm{~h}\end{array}$ & 17 & M & 3.68 & 5.40 & 25.5 & 5.9 & E. coli & Pneumonia \\
\hline $\begin{array}{l}10 \\
27 \mathrm{~h}\end{array}$ & 45 & M & 47.34 & 45.75 & 30.08 & 8.1 & E. coli & Necrotizing fasciitis \\
\hline $\begin{array}{l}11 \\
18 \mathrm{~h}\end{array}$ & 39 & M & 12.34 & 1.81 & 24.2 & 11.4 & n.i. & $\begin{array}{l}\text { Abdominal and pelvic } \\
\text { infection }\end{array}$ \\
\hline $\begin{array}{l}12 \\
24 \mathrm{~h}\end{array}$ & 44 & M & 7.55 & 3.65 & 31.3 & 8.1 & K. pneumoniae & Pneumonia \\
\hline
\end{tabular}

n.i. not clearly identifiable pathogens, $m . b$. multiple bacteria

analyses on postmortem serum from femoral blood, whole blood, pericardial fluid, and vitreous humor. Microbiology was not performed in any of the cases in this group.

Causes of death were determined to be drug intoxication (eight cases), drowning (two cases), positional asphyxia (one case), trauma post-traffic accident (five cases), stab wounds (four cases), gunshot wounds (five cases), and natural cardiac death (five cases).

Postmortem investigations failed to reveal findings consistent with the existence of underlying bacterial infections or septic states. Descriptive characteristics of the control group subjects, main postmortem investigation findings, and causes of death are reported in Table 2.

Sample collection

Femoral blood and postmortem serum from femoral blood

Using a sterile needle and syringe, postmortem blood samples were collected by aspiration through the femoral vein during the autopsy. Part of the sample was centrifuged immediately post-collection at $3,000 \times \mathrm{g}$ for $15 \mathrm{~min}$. After centrifugation, the separated supernatant (postmortem serum) was collected, stored in preservative-free tubes, and frozen at $-20{ }^{\circ} \mathrm{C}$ until analysis.

\section{Right cardiac blood}

The external side of the right atrium was sterilized by searing with a flamed scalpel blade. The cardiac blood was aspired with a syringe and stored in blood culture bottles (aerobic and anaerobic). The collected samples were immediately incubated at $37^{\circ} \mathrm{C}$.

\section{Pericardial fluid}

Undiluted samples of pericardial fluid were collected immediately post-pericardium incision during autopsy. All samples were immediately centrifuged at $3,000 \times g$ for $15 \mathrm{~min}$. After centrifugation, the separated supernatant 
Table 2 Summarizes the characteristics of the investigated subjects (control individuals, $n=30,15$ males and 15 females, mean age 39.2 ), laboratory results, main postmortem investigation findings, and causes of death

\begin{tabular}{|c|c|c|c|c|c|c|c|}
\hline $\begin{array}{l}\text { Subject and } \\
\text { postmortem interval }\end{array}$ & Age & Gender & $\begin{array}{l}\text { Postmortem serum } \\
\text { procalcitonin }\end{array}$ & $\begin{array}{l}\text { Pericardial fluid } \\
\text { procalcitonin }\end{array}$ & $\begin{array}{l}\text { Postmortem } \\
\text { serum LBP }\end{array}$ & $\begin{array}{l}\text { Pericardial } \\
\text { fluid LBP }\end{array}$ & $\begin{array}{l}\text { Main postmortem } \\
\text { investigation findings }\end{array}$ \\
\hline $\begin{array}{l}1 \\
19 \mathrm{~h}\end{array}$ & 18 & $\mathrm{~F}$ & 0.06 & 0.06 & 2.1 & 2.0 & Trauma (traffic accident) \\
\hline $\begin{array}{l}2 \\
26 \mathrm{~h}\end{array}$ & 32 & M & 0.06 & 0.06 & 5.2 & 3.9 & Trauma (traffic accident) \\
\hline $\begin{array}{l}3 \\
15 \mathrm{~h}\end{array}$ & 50 & $\mathrm{~F}$ & 0.06 & 0.06 & 4.1 & 3.7 & Gunshot wounds \\
\hline $\begin{array}{l}4 \\
21 \mathrm{~h}\end{array}$ & 25 & M & 0.06 & 0.06 & 3.9 & 3.5 & Stab wounds \\
\hline $\begin{array}{l}5 \\
23 \mathrm{~h}\end{array}$ & 20 & $\mathrm{~F}$ & 0.06 & 0.06 & 8.1 & 5.6 & Stab wounds \\
\hline $\begin{array}{l}6 \\
39 \mathrm{~h}\end{array}$ & 69 & M & 0.06 & 0.06 & 3.2 & 3.0 & Natural death (cardiac) \\
\hline $\begin{array}{l}7 \\
51 \mathrm{~h}\end{array}$ & 71 & $\mathrm{~F}$ & 0.06 & 0.06 & 2.2 & 2.1 & Natural death (cardiac) \\
\hline $\begin{array}{l}8 \\
8 \mathrm{~h}\end{array}$ & 44 & M & 0.06 & 0.06 & 7.0 & 3.5 & Trauma (traffic accident) \\
\hline $\begin{array}{l}9 \\
14 \mathrm{~h}\end{array}$ & 22 & $\mathrm{~F}$ & 0.06 & 0.06 & 4.7 & 3.2 & Trauma (traffic accident) \\
\hline $\begin{array}{l}10 \\
19 \mathrm{~h}\end{array}$ & 38 & M & 0.06 & 0.06 & 2.8 & 2.4 & Trauma (traffic accident) \\
\hline $\begin{array}{l}11 \\
23 \mathrm{~h}\end{array}$ & 70 & $\mathrm{~F}$ & 0.06 & 0.06 & 6.9 & 5.1 & Natural death (cardiac) \\
\hline $\begin{array}{l}12 \mathrm{~h} \\
39 \mathrm{~h}\end{array}$ & 30 & M & 0.06 & 0.06 & 3.3 & 2.5 & Drug intoxication \\
\hline $\begin{array}{l}13 \\
11 \mathrm{~h}\end{array}$ & 29 & $\mathrm{~F}$ & 0.06 & 0.06 & 5.6 & 4.4 & Stab wounds \\
\hline $\begin{array}{l}14 \\
16 \mathrm{~h}\end{array}$ & 21 & M & 0.06 & 0.06 & 5.3 & 4.2 & Stab wounds \\
\hline $\begin{array}{l}15 \\
27 \mathrm{~h}\end{array}$ & 35 & $\mathrm{~F}$ & 0.06 & 0.06 & 8.5 & 7.7 & Drug intoxication \\
\hline $\begin{array}{l}16 \\
24 \mathrm{~h}\end{array}$ & 37 & M & 0.06 & 0.06 & 4.4 & 3.2 & Gunshot wounds \\
\hline $\begin{array}{l}17 \\
20 \mathrm{~h}\end{array}$ & 19 & $\mathrm{~F}$ & 0.06 & 0.06 & 6.3 & 4.9 & Drug intoxication \\
\hline $\begin{array}{l}18 \\
21 \mathrm{~h}\end{array}$ & 30 & M & 0.06 & 0.06 & 6.5 & 5.5 & Gunshot wounds \\
\hline $\begin{array}{l}19 \\
18 \mathrm{~h}\end{array}$ & 32 & $\mathrm{~F}$ & 0.06 & 0.06 & 7.4 & 6.2 & Gunshot wounds \\
\hline $\begin{array}{l}20 \\
31 \mathrm{~h}\end{array}$ & 69 & M & 0.06 & 0.06 & 4.5 & 4.4 & Natural death (cardiac) \\
\hline $\begin{array}{l}21 \\
32 \mathrm{~h}\end{array}$ & 43 & $\mathrm{~F}$ & 0.06 & 0.06 & 7.0 & 3.5 & Drug intoxication \\
\hline $\begin{array}{l}22 \\
16 \mathrm{~h}\end{array}$ & 21 & M & 0.06 & 0.06 & 5.8 & 3.8 & Drug intoxication \\
\hline $\begin{array}{l}23 \\
23 \mathrm{~h}\end{array}$ & 36 & $\mathrm{~F}$ & 0.06 & 0.06 & 8.4 & 17.9 & Gunshot wounds \\
\hline $\begin{array}{l}24 \\
20 \mathrm{~h}\end{array}$ & 68 & M & 0.06 & 0.06 & 3.7 & 2.9 & Natural death (cardiac) \\
\hline $\begin{array}{l}25 \\
24 \mathrm{~h}\end{array}$ & 23 & $\mathrm{~F}$ & 0.06 & 0.06 & 6.5 & 5.4 & Drug intoxication \\
\hline $\begin{array}{l}26 \\
33 \mathrm{~h}\end{array}$ & 39 & $\mathrm{~F}$ & 0.06 & 0.06 & 7.6 & 6.8 & Drowning \\
\hline 27 & 41 & $\mathrm{~F}$ & 0.06 & 0.06 & 2.6 & 12.2 & Drug intoxication \\
\hline
\end{tabular}


Table 2 (continued)

\begin{tabular}{lccccccc}
\hline $\begin{array}{l}\text { Subject and } \\
\text { postmortem interval }\end{array}$ & Age & Gender & $\begin{array}{l}\text { Postmortem serum } \\
\text { procalcitonin }\end{array}$ & $\begin{array}{l}\text { Pericardial fluid } \\
\text { procalcitonin }\end{array}$ & $\begin{array}{l}\text { Postmortem } \\
\text { serum LBP }\end{array}$ & $\begin{array}{l}\text { Pericardial } \\
\text { fluid LBP }\end{array}$ & $\begin{array}{l}\text { Main postmortem } \\
\text { investigation findings }\end{array}$ \\
\hline $\begin{array}{l}30 \mathrm{~h} \\
28\end{array}$ & 36 & $\mathrm{M}$ & 0.06 & 0.06 & 12.2 & 6.1 & Drowning \\
$\begin{array}{l}24 \mathrm{~h} \\
29\end{array}$ & 46 & $\mathrm{M}$ & 5.21 & & & & \\
$51 \mathrm{~h}$ & 61 & $\mathrm{M}$ & 8.26 & 5.55 & 5.0 & 3.2 & Drug intoxication \\
30 & & & & 5.51 & 6.2 & 9.1 & Positional asphyxia \\
$24 \mathrm{~h}$ & & & & & & \\
\hline
\end{tabular}

was collected, stored in preservative-free tubes, and frozen at $-20{ }^{\circ} \mathrm{C}$ until analysis.

\section{Laboratory assays}

\section{Determination of procalcitonin concentration}

PCT was measured with the commercially available immunoassays on the Roche Modular E170 analyzer (Roche Diagnostic, Mannheim, Germany). The results were expressed in micrograms per liter. The analytical sensitivity for PCT was $0.1 \mu \mathrm{g} / \mathrm{l}$, according to manufacturer information.

\section{Determination of LBP concentration}

LBP was determined by chemiluminescent immunometric assay Immulite ${ }^{\circledR} 2000$ (Siemens Medical, Germany). The results were expressed in micrograms per milliliter. The analytical sensitivity for LBP was $0.2 \mu \mathrm{g} / \mathrm{ml}$, according to manufacturer information.

\section{Other analyses}

Other biochemical analyses were performed according to the laboratory standards and internal quality control protocols.

\section{Ethical considerations}

All cases collected for this study underwent medicolegal autopsies requested by the public prosecutor. Biochemical analyses, including PCT, CRP, and LBP determinations, were performed as part of the medicolegal investigations and no further ethical permission was required to perform laboratory analyses.

\section{Statistical analyses}

The data were analyzed by using STATA statistical software package (STATA Corporation, College Station, TX, USA). Receiver operator characteristic (ROC) curves, sensitivity, and specificity values were calculated to assess the performance of the selected biomarkers as diagnostic markers for sepsis. Diagnostic accuracy was determined by the area under the curves (AUC) of the studied markers. According to laboratory references, procalcitonin values were dichotomized into "non-septic values" (concentrations lower than $2 \mu \mathrm{g} / \mathrm{l}$ ) and "septic values" (concentrations greater than $2 \mu \mathrm{g} / \mathrm{l})$. Analogously, LBP values were dichotomized into "normal values" (concentrations lower than $10 \mu \mathrm{g} / \mathrm{ml}$ ) and "increased values" (concentrations greater than $10 \mu \mathrm{g} / \mathrm{ml}$ ).

\section{Results}

Descriptive characteristics of the studied subjects, laboratory results, causes of death, and statistical results are reported in Tables 1, 2, and 3.

\section{Postmortem serum}

In the 12 cases included in the sepsis group, the cause of death was attributed to multiple organ failure based on the results of postmortem investigations as well as the exclusion of other causes of death. Underlying bacterial septic states were postulated as being at the origin of the multiple organ failures.

Assuming that normal and pathological PCT and LBP blood levels in living people show similar ranges in postmortem serum from femoral blood, only one individual (case 4) among the sepsis-related fatalities presented a normal postmortem serum PCT value $(0.06 \mu \mathrm{g} / 1)$, with an increased postmortem serum LBP level $(15.4 \mu \mathrm{g} / \mathrm{ml})$. Blood cultures revealed the presence of multiple Gram-positive- and Gramnegative bacteria. Histology showed the presence of multiple foci of polynuclear neutrophils in both lungs. According to medical records, the patient suffered from pneumonia and had received antibiotic treatment 5 days prior to death.

Conversely, one individual among the sepsis-related fatalities (case 1) presented a normal postmortem serum LBP value (6.1 $\mu \mathrm{g} / \mathrm{ml})$, whereas the postmortem serum PCT level was increased $(23.37 \mu \mathrm{g} / \mathrm{l})$. Increased levels of both postmortem serum PCT and LBP were observed in 10 out of 12 septic cases. 
Table 3 Summarizes sensitivity, specificity, and area under the curve (AUC) for procalcitonin (PCT) and lipopolysaccharidebinding protein (LBP) in postmortem serum (S) and pericardial fluid (PF)

\begin{tabular}{llllll}
\hline & PCT & PCT & LBP & LBP & PCT and LBP \\
& S & PF & PF & S \\
\hline Sensitivity & $91.67 \%$ & $75.00 \%$ & $91.67 \%$ & $16.67 \%$ & $83.33 \%$ \\
Specificity & $93.33 \%$ & $93.33 \%$ & $96.67 \%$ & $93.33 \%$ & $100 \%$ \\
AUC & 0.93 & 0.92 & 0.96 & 0.81 & 0.99 \\
False-positive & 2 & 2 & 1 & 2 & 0 \\
False-negative & 1 & 3 & 1 & 10 & 2 \\
\hline
\end{tabular}

In the 30 control cases, postmortem investigations failed to reveal findings consistent with the existence of underlying bacterial infections or septic states. Again, assuming that normal and pathological PCT and LBP blood levels in living people show similar ranges in postmortem serum from femoral blood, two cases were observed that revealed increased postmortem serum PCT values and normal LBP concentrations (case 29, drug intoxication, PCT $5.21 \mu \mathrm{g} / \mathrm{l}$ and LBP $5.0 \mu \mathrm{g} / \mathrm{ml}$; case 30, positional asphyxia, PCT $8.26 \mu \mathrm{g} / \mathrm{l}$ and LBP $6.2 \mu \mathrm{g} / \mathrm{ml}$;) and one case of drowning (case 28) showing a normal postmortem serum PCT value $(0.06 \mu \mathrm{g} / \mathrm{l})$ but an increased postmortem serum LBP level $(12.2 \mu \mathrm{g} / \mathrm{ml})$.

As expected, postmortem serum PCT levels were higher in the sepsis group and differed between the two groups, with only one false-negative case in the sepsis group (which conversely showed an increased LBP value) and two falsepositives in the control group (which conversely showed normal LBP values). However, assuming that there are a number of noninfectious situations that may result in increased PCT levels, one might speculate on the possibility that these two "false positive" septic cases were indeed "true negative" nonseptic cases, as confirmed by normal LBP values.

Similarly, postmortem serum LBP levels were higher in the sepsis group and differed between the two groups, with only one false-negative case in the sepsis group (which conversely showed an increased PCT value) and one falsepositive case in the control group (which conversely showed a normal PCT value).

None of the control cases showed increases in both marker values at the same time. PCT determination in postmortem serum in both septic and control groups allowed us to confirm the diagnostic accuracy of this biomarker in detecting sepsis-related fatalities (sensitivity $91.67 \%$, specificity $93.33 \%$, AUC 0.93). Similarly, LBP determination in postmortem serum in both studied groups also allowed septic states (sensitivity $91.67 \%$, specificity $96.67 \%$, AUC 0.96) to be identified.

Increases in both postmortem serum PCT and LBP levels were only observed in septic cases. Analogously, both normal PCT and LBP levels were only found in non-septic cases, thereby suggesting that converging PCT and LBP results represent a useful tool in confirming the septic nature of a specific case (sensitivity $83.33 \%$, specificity $100 \%$, AUC 0.99 ).
Pericardial fluid

Assuming that normal and pathological PCT and LBP blood levels in living people show similar ranges in postmortem pericardial fluid (concentrations greater than $2 \mu \mathrm{g} / \mathrm{l}$ for PCT and greater than $10 \mu \mathrm{g} / \mathrm{ml}$ for LBP), pericardial fluid PCT levels were higher in the sepsis group and differed between sepsis and control individuals (sensitivity $75.00 \%$, specificity $93.33 \%$, AUC 0.92).

Pathologically increased postmortem serum PCT levels in the sepsis group in 11 cases were reflected in pathologically increased pericardial fluid PCT levels in nine cases. Among the control cases, postmortem serum PCT levels below the detection limit in 28 cases were reflected in undetectable pericardial fluid levels in the same 28 cases. These data concur with those of Schrag et al. [1] who concluded that procalcitonin can be measured in pericardial fluid and provide useful information for forensic purposes when postmortem serum is unavailable.

Lastly, the results of the data analysis revealed that pericardial fluid LBP levels were similar in the studied groups. Postmortem serum and pericardial fluid LBP values in both septic and non-septic groups were incomparable, as well as pericardial fluid PCT and LBP levels (sensitivity $16.67 \%$, specificity $93.33 \%$, AUC 0.81), suggesting that the determination of LBP in pericardial fluid does not appear to be an alternative option should postmortem serum be unavailable.

\section{Right cardiac blood}

Since neither antemortem blood cultures nor documented diagnosis of sepsis in vivo were available for the cases included in the sepsis group, results obtained from microbiology were cautiously interpreted due to the possibility of postmortem contamination.

\section{Discussion}

The aim of this study was to investigate the diagnostic performance of two biochemical markers, PCT and LBP, combined or individually considered, to identify sepsis- 
related fatalities. We furthermore wished to test the usefulness of pericardial fluid for LBP determination.

Concerning the first objective, the results of this study showed that postmortem serum PCT and LBP levels, individually considered, allow sepsis cases to be reliably detected. Additionally, increases in both parameters in postmortem serum were observed only in septic cases, suggesting that coherent PCT and LBP results can be used in forensic routine in order to corroborate the existence of underlying, bacterial septic states.

Reliable diagnoses of sepsis are of utmost importance in forensic pathology routine, firstly due to the lack of detailed medical records when bodies are admitted to the mortuary for medicolegal investigations, secondly because macroscopic and microscopic findings may be elusive or nonspecific. Thus, biochemical markers that could discriminate between sepsis-related fatalities and noninfectious SIRS would be of great importance in this field.

Several biochemical markers have been proposed in recent years as potential parameters differentiating between infectious and noninfectious SIRS in both clinical and forensic medicine [1-3, 26-32]. The discriminative value of CRP and interleukin-6 in distinguishing sepsis from noninfectious SIRS is somehow limited due to the fact that both biomarkers are nonspecific indicators of underlying inflammatory processes rather than bacterial sepsis $[2,29]$.

PCT has been evaluated in multiple clinical settings as a laboratory tool in differentiating bacterial infections from other inflammatory states and infectious processes [33, 34]. Four meta-analyses have reported on PCT performance in the diagnosis of sepsis with conflicting results. Two studies suggested that PCT is superior to other biochemical parameters, whereas two other studies found PCT to have either a moderate or poor ability in identifying sepsis in critically ill, adult patients [35-39].

In neonatal sepsis, PCT seems to better discriminate SIRS from sepsis as well as bacterial infections from non-bacterial infections in comparison with other biomarkers, though it is not statistically more accurate than CRP $[23,40]$. Adequate laboratory diagnostics therefore represent a major requirement for improving the diagnosis of sepsis [41].

Sepsis is not a single disease but rather a highly heterogeneous syndrome that is the final result of host and pathogen interactions triggering networks of biochemical mediators and inflammatory cascades. Clinical expression is therefore variable and severity is influenced by several factors including type of pathogen, infection site, clinical interventions, and host factors, such as genetics and baseline health [34].

LBP belongs to the acute-phase proteins and is mainly synthesized by hepatocytes but by epithelial and muscle cells as well [23, 42]. LBP binds and recruits endotoxin to the surface of Gram-negative bacteria very early during infection. Under physiologic circumstances, LBP binds Gram-negative bacteria via the lipid A part of LPS, which mediates its binding to the CD14 cellular receptor molecule presented by monocytes and macrophages. This results in phagocytosis and clearance of these microorganisms [23, 43]. LBP plasma levels have been investigated in various human populations: in healthy subjects, LBP plasma concentrations range from 2 to $10 \mu \mathrm{g} / \mathrm{ml}$ [44] whereas very high plasma levels, exceeding $100 \mu \mathrm{g} / \mathrm{ml}$, have been observed in patients with sepsis, SIRS, abdominal infections, ulcerative colitis, and many other diseases. Pavcnik-Arnol et al. [45] found that LBP was an early marker that differentiated between noninfectious SIRS and sepsis in critically ill neonates and children with high accuracy. The LBP cutoff value of $>7.4 \mu \mathrm{g} / \mathrm{ml}$ identifying septic syndrome has been reported for newborns and is nearly identical for adults [46].

In forensic pathology literature, no studies have been performed to compare the discriminative values of LBP and PCT for the postmortem diagnosis of sepsis-related fatalities. Reichelt et al. [25] investigated the postmortem behavior of LPB in two groups of septic and non-septic individuals and observed a decreasing trend of LBP postmortem serum levels in both groups with postmortem interval progression. The authors correlated such decreasing concentrations namely to the postmortem proteolysis of the molecule with the onset of significant hemolysis. Based on the results of their investigations, the authors concluded that LBP postmortem serum levels above $10 \mu \mathrm{g} / \mathrm{ml}$ could be considered diagnostic clues for underlying sepsis and proposed at least two measurements at different postmortem intervals to better estimate the most probable LBP level at the time of death by using linear regression analysis. Lastly, they emphasized that in order to prove underlying sepsis at the time of death beyond any reasonable doubt, combinations of several biomarkers of sepsis should be recommended.

Groselj-Grenc et al. [40] and Pavcnik-Arnol et al. [45, 47] compared the diagnostic accuracy of LBP and other biochemical markers, including PCT, in differentiating bacterial sepsis from non-bacterial SIRS in critically ill neonates and children, concluding that LBP was a better marker of sepsis than PCT in neonates. The study herein presented is the first analysis assessing the diagnostic value of LBP and PCT for the postmortem detection of sepsis as well as the first study to compare pericardial fluid PCT and LBP levels.

The results of our investigations indicate high diagnostic accuracy for both parameters, individually considered and combined, in detecting sepsis-related outcomes in the postmortem period. It is known that LBP levels may increase after extensive cardiothoracic surgical procedures and decrease after death due to the onset of postmortem phenomena $[24,25]$. Similarly, numerous non-septic situations can be characterized by increased PCT values [7, 8, 10-17]. Our 
findings indicate that increases in both postmortem serum PCT and LBP levels may corroborate the existence of underlying septic states.

Though further studies and investigations are required to confirm these findings, the results of our data analysis also indicate that pericardial fluid LBP levels do not correlate with the presence of increased postmortem serum LBP levels, in contrast with pericardial fluid PCT levels, which have been shown to correlate well with postmortem serum values.

No associations were identified between postmortem serum and pericardial fluid LBP levels in either septic or nonseptic groups, nor between pericardial fluid PCT and LBP levels. Hence, the determination of LBP in pericardial fluid cannot be considered an alternative to postmortem serum in situations in which postmortem biochemistry could help in determining the cause of death and neither peripheral nor cardiac blood are available upon autopsy.

Acknowledgments The authors kindly acknowledge Siemens Medical Switzerland for providing the LBP test and for their help in performing the analyses. The authors gratefully acknowledge the assistance of the editors and anonymous reviewers of the journal for their comments and suggestions.

Conflict of interest The authors have no conflict of interest to declare. Siemens Medical Switzerland had no role in the study design, data collection, data analysis, data interpretation, or writing of the report. No financial support was received from Siemens Medical Switzerland for the preparation of this manuscript, the material used for the analyses, the laboratory equipment, or laboratory personnel involved in the study.

\section{References}

1. Schrag B, Iglesias K, Mangin P, Palmiere C (2012) Procalcitonin and C-reactive protein in pericardial fluid for postmortem diagnosis of sepsis. Int J Leg Med 126(4):567-572

2. Schrag B, Roux-Lombard P, Schneiter D, Vaucher P, Mangin P, Palmiere C (2012) Evaluation of C-reactive protein, procalcitonin, tumor necrosis factor alpha, interleukin- 6 , and interleukin- 8 as diagnostic parameters in sepsis-related fatalities. Int $\mathrm{J}$ Leg Med 126(4):505-512

3. Astrup BS, Thomsen JL (2007) The routine use of C-reactive protein in forensic investigations. Forensic Sci Int 172(1):49-55

4. Engel A, Mack E, Kern P, Kern WV (1998) An analysis of interleukin-8, interleukin-6 and C-reactive protein to predict fever, gram-negative bacteremia and complicated infection in neutropenic cancer patients. Infection 26(4):213-221

5. Reinhart K, Meisner M, Brinkhorst FM (2006) Markers for sepsis diagnosis: what is useful? Crit Care Clin 22(6):503-519

6. Meisner M, Tschaikowsky K, Palmaers T, Schmidt J (1999) Comparison of procalcitonin (PCT) and C-reactive protein (CRP) plasma concentrations at different SOFA scores during the course of sepsis and MODS. Crit Care 3(1):45-50

7. Eberhard OK, Haubitz M, Brunkhorst FM, Kliem V, Koch KM, Brunkhorst R (1997) Usefulness of procalcitonin for differentiation between activity of systemic autoimmune disease (systemic lupus erythematosus/systemic antineutrophil cytoplasmic antibody- associated vasculitis) and invasive bacterial infection. Arthritis Rheum 40(7):1250-1256

8. Lindahl B, Toss H, Siegbahn A, Venge P, Wallentin L (2000) Markers of myocardial damage and inflammation in relation to long-term mortality in unstable coronary artery disease. FRISC Study Group. Fragmin during instability in coronary artery disease. N Engl J Med 343(16):1139-1147

9. Brunkhorst FM, Heinz U, Forycki ZF (1998) Kinetics of procalcitonin in iatrogenic sepsis. Intensive Care Med 24(8):888-889

10. Dandona P, Nix D, Wilson MF, Aljada A, Love J, Assicot M, Bohuon C (1994) Procalcitonin increase after endotoxin injection in normal subject. J Clin Endocrinol Metab 79(6):1605-1608

11. Tong HS, Liu YS, Wen Q, Tang YQ, Yuan FF, Su L (2012) Serum procalcitonin predicting mortality in exertional heatstroke. Emerg Med J 29(2):113-117

12. Hausfater P, Hurtado M, Pease S, Juillien G, Lvovschi VE, Salehabadi S, Lidove O, Wollf M, Bernard M, Chollet-Martin S, Riou B (2008) Is procalcitonin a marker of critical illness in heatstroke? Intensive Care Med 34(8):1377-1383

13. Nylén ES, Al Arifi A, Becker KL, Snider RH Jr, Alzeer A (1997) Effect of classic heatstroke on serum procalcitonin. Crit Care Med 25(8):1362-1365

14. Balci C, Sivaci R, Akbulut G, Karabekir HS (2009) Procalcitonin levels as an early marker in patients with multiple trauma under intensive care. J Int Med Res 37(6):1709-1717

15. Maier M, Wutzler S, Lehnert M, Szermutzky M, Wyen H, Bingold T, Henrich D, Walcher F, Marzi I (2009) Serum procalcitonin levels in patients with multiple injuries including visceral trauma. J Trauma 66(1):243-249

16. Brunkhorst FM, Clark AL, Forycki ZF, Anker SD (1999) Pyrexia, procalcitonin, immune activation and survival in cardiogenic shock: the potential importance of bacterial translocation. Int $\mathrm{J}$ Cardiol 72(1):3-10

17. Brunkhorst FM (1999) Endotoxins in chronic heart failure. Lancet 354(9178):599-600

18. Tobias PS, Soldau K, Ulevitch RJ (1986) Isolation of a lipopolysaccharide-binding acute phase reactant from rabbit serum. J Exp Med 164(3):777-793

19. Wurfel MM, Kunitake ST, Lichenstein H, Kane JP, Wright SD (1994) Lipopolysaccharide (LPS)-binding protein is carried on lipoproteins and acts as a cofactor in the neutralisation of LPS. J Exp Med 180(3):1025-1035

20. Sakr Y, Burgett U, Nacul FE, Reinhart K, Brunkhost F (2008) Lipopolysaccharide binding protein in a surgical intensive care unit: a marker of sepsis? Crit Care Med 36(7):2014-2022

21. Tobias PS, Mathison J, Mintz D, Lee JD, Kravchenko V, Kato K, Pugin J, Ulevitch RJ (1992) Participation of lipopolysaccharidebinding protein in lipopolysaccharide-dependent macrophage activation. Am J Respir Cell Mol Biol 7(3):239-245

22. Berner R, Fürll B, Stelter F, Dröse J, Müller HP, Schütt C (2002) Elevated levels of lipopolysaccharide-binding protein and soluble CD14 in plasma in neonatal early-onset sepsis. Clin Diagn Lab Immunol 9(2):440-445

23. Mussap M, Noto A, Fravega M, Fanos V (2011) Soluble CD14 subtype presepsin (sCD14-ST) and lipopolysaccharide binding protein (LBP) in neonatal sepsis: new clinical and analytical perspectives for two old biomarkers. J Matern Fetal Neonatal Med 24(Suppl 2):12-14

24. Meynaar IA, Droog W, Batstra M, Vreede R, Herbrink P (2011) In critically ill patients, serum procalcitonin is more useful in differentiating between sepsis and SIRS than CRP, Il-6, or LBP. Crit Care Res Pract. doi:10.1155/2011/594645

25. Reichelt U, Jung R, Nierhaus A, Tsokos M (2005) Serial monitoring of interleukin- $1 \beta$, soluble interleukin-2 receptor and lipopolysaccharide binding protein levels after death. A comparative evaluation of potential postmortem markers of sepsis. Int J Legal Med 119(2):80-87 
26. Bouma M, Maessen J, Weerwind P, Dentener M, Fransen E, de Jong D, Buurman W (1997) Release of lipopolysaccharide toxicity-modulating proteins in patients undergoing cardiopulmonary bypass using noncoated and heparin-coated extracorporeal circuits. A clinical pilot study. Chest 111(3):577-583

27. Franke A, Lante W, Fackeldey V, Becker HP, Kurig E, Zöller LG, Weinhold C, Markewitz A (2005) Pro-inflammatory cytokines after different kinds of cardio-thoracic surgical procedures: is what we see what we know? Eur J Cardiothorac Surg 28 (4):569-575

28. Tsokos M, Reichelt U, Nierhaus A, Püschel K (2001) Serum procalcitonin (PCT): a valuable biochemical parameter for the postmortem diagnosis of sepsis. Int J Leg Med 114(4-5):237-243

29. Tsokos M, Reichelt U, Jung R, Nierhaus A, Püschel K (2001) Interleukin-6 and C-reactive protein serum levels in sepsis-related fatalities during the early postmortem period. Forensic Sci Int 119 (1):47-56

30. Ramsthaler F, Kettner M, Mall G, Bratzke H (2008) The use of rapid diagnostic test of procalcitonin serum levels for the postmortem diagnosis of sepsis. Forensic Sci Int 178(2-3):139-145

31. Uhlin-Hansen L (2001) C-reactive protein (CRP), a comparison of pre- and postmortem blood levels. Forensic Sci Int 124(1):32-35

32. Fujita MQ, Zhu BL, Ishida K, Quan L, Oritani S, Maeda H (2002) Serum C-reactive protein levels in postmortem blood-an analysis with special reference to the cause of death and survival time. Forensic Sci Int 130(2-3):160-166

33. Christ-Crain M, Müller B (2005) Procalcitonin in bacterial infectionshype, hope, more or less? Swiss Med Wkly 135(31-32):451-460

34. Tsalik EL, Jaggers LB, Glickman SW, Langley RJ, van Velkinburgh JC, Park LP, Fowler VG, Cairns CB, Kingsmore SF, Woods CW (2012) Discriminative value of inflammatory biomarkers for suspected sepsis. J Emerg Med 43(1):97-106

35. Simon L, Gauvin F, Amre DK, Saint-Louis P, Lacroix J (2004) Serum procalcitonin and C-reactive protein levels as markers of bacterial infection: a systematic review and meta-analysis. Clin Infect Dis 39(2):206-217

36. Jones AE, Fiechtl JF, Brown MD, Ballew JJ, Kline JA (2007) Procalcitonin test in the diagnosis of bacteremia: a meta-analysis. Ann Emerg Med 50(1):34-41

37. Tang BM, Eslick GD, Craig JC, McLean AS (2007) Accuracy of procalcitonin for sepsis diagnosis in critically ill patients: systematic review and meta-analysis. Lancet Infect Dis 7 (3):210-217

38. Uzzan B, Cohen R, Nicolas P, Cucherat M, Perret GY (2006) Procalcitonin as a diagnostic test for sepsis in critically ill adults and after surgery or trauma: a systematic review and meta-analysis. Crit Care Med 34(7):1996-2003

39. Mann EA, Wood GL, Wade CE (2011) Use of procalcitonin for the detection of sepsis in the critically ill burn patients: a systematic review of the literature. Burns 37(4):549-558

40. Groselj-Grenc M, Ihan A, Pavcnik-Arnol M, Kopitar AN, GmeierStopar T, Derganc M (2009) Neutrophil and monocytes CD64 indexes, lipopolysaccharide-binding protein, procalcitonin and $\mathrm{C}$ reactive protein in sepsis of critically ill neonates and children. Intensive Care Med 35(11):1950-1958

41. Herzum I, Renz H (2008) Inflammatory markers in SIRS, sepsis and septic shock. Curr Med Chem 15(6):581-587

42. Zweigner J, Schumann RR, Weber JR (2006) The role of lipopolysaccharide-binding protein in modulating the innate immune response. Microbes Infect 8(3):946-952

43. Prucha M, Herold I, Zazula R, Dubska L, Dostal M, Hildebrand T, Hyanek J (2003) Significance of lipopolysaccharide-binding protein (an acute phase protein) in monitoring critically ill patients. Crit Car 7(6):R154-R159

44. Zweigner J, Gramm HJ, Singer OC, Wegscheider K, Schumann RR (2001) High concentrations of lipopolysaccharide-binding protein in serum of patients with severe sepsis or septic shock inhibit the lipopolysaccharide response in human monocytes. Blood 98 (13):3800-3808

45. Pavcnik-Arnol M, Hojker S, Derganc M (2007) Lipopolysaccharidebinding protein, lipopolysaccharide, and soluble CD14 in sepsis of critically ill neonates and children. Intensive Care Med 33(6):10251032

46. Opal SM, Scannon PJ, Vincent JL, White M, Carroll SF, Palardy JE, Parejo NA, Pribble JP, Lemke JH (1999) Relationship between plasma levels of lipopolysaccharide (LPS) and LPS-binding protein in patients with severe sepsis and septic shock. J Infect Dis 180(5):1584-1589

47. Pavcnik-Arnol M, Hojker S, Derganc M (2004) Lipopolysaccharidebinding protein in critically ill neonates and children with suspected infection: comparison with procalcitonin, interleukin-6, and Creactive protein. Intensive Care Med 30(7):1454-1460 